Pierre Foëx MA DPHIL FRCA FANZCA, S.J. Howell MSC MRCP FRCA

\section{The myocardium}

because bradycardia and hypotension reduce oxygen demand. However, if the bradycardia resulting from vagal stimulation is prevented by pacing, coronary blood flow increases uniformly across the left ventricular wall in response to vagal stimulation. By contrast, acetylcholine preferentially vasodilates the vessels of the subendocardium. ${ }^{10}$

While the role of the autonomic nervous system in the control of the coronary circulation has long been underestimated, many studies of patients with variant angina suggest that there is local nonspecific supersensitivity to vasoconstrictors. ${ }^{11}$ Alpha-adrenergic constriction of coronary resistance vessels may result in the precipitation of post-stenotic myocardial ischaemia both in experimental models and in patients with effort angina. In contrast, the adverse effects of beta-adrenergic stimulation are a consequence of the tachycardia and the tachycardia-related redistribution of coronary blood flow, as the vasodilatation is of little functional significance when the tachycardia is allowed to develop. ${ }^{12}$

The carotid baroreceptors play a role in the control of the coronary circulation: carotid sinus hypertension results in a graded reflex neural coronary vasodilatation independent of myocardial metabolic factors. The major component appears to be the activation of parasympathetic coronary vasodilator fibres. ${ }^{13}$

\section{Myocardial ischaemia}

Progressive regional myocardial ischaemia causes a gradual reduction in systolic shortening (thickening) of the cardiac fibres associated with abnormal patterns of wall motion such as early systolic lengthening (thinning) and post-systolic shortening (thickening). ${ }^{14-15}$ In clinical practice, these abnormalities of wall motion are described as hypokinesia (reduced wall motion), akinesia (absence of wall motion) and dyskinesia (paradoxical wall motion). Because of regional interactions, increased wall motion of distant normally perfused myocardium is often observed during regional ischaemia. ${ }^{16}$

It is now recognized that diastolic function may be altered in ischaemic and hypertensive heart disease before systolic function is reduced. Acute myocardial ischaemia causes profound alterations of diastolic function. Because of the dyssynchrony of isovolumic relaxation (post-systolic shortening or thickening), the

Pierre Foëx and SJ Howell

Nuffield Department of Anacsthetics, Oxford, England. 
time constant of isovolumic relaxation $(\tau)$ is prolonged. In ischaemic segments, the maximum rate of lengthening (or thinning) is reduced; this is a direct consequence of the reduced extent of systolic shortening (thickening). In addition, myocardial stiffness is increased. This increase is directly related to the severity of ischaemia and reaches a maximum with coronary occlusion. Though the mechanisms are as yet unknown, regional myocardial ischaemia is associated with an increase in stiffness of distant, well perfused myocardium. ${ }^{17}$ This effect of ischaemia at a distance may contribute to the increase in left ventricular enddiastolic pressure observed during episodes of regional ischaemia.

For many years the concept prevailed that prolonged episodes of severe ischaemia caused irreversible myocardial injury i.e., myocardial infarction, while brief episodes of ischaemia were followed by prompt total recovery. This concept has been challenged and the concepts of myocardial stunning and myocardial hibernation have evolved. It is now accepted that patients with myocardial ischaemia may develop left ventricular failure because of irreversible damage (cell death), myocardial stunning, or myocardial hibernation.

\section{Myocardial stunning}

In 1982, Braunwald and Kloner coined the term myocardial "stunning" to describe the prolonged contractile dysfunction that persists after acute severe ischaemia followed by reperfusion. ${ }^{18}$ This contractile dysfunction includes decreased systolic function (systolic stunning) and increased myocardial stiffness (diastolic stunning). Myocardial stunning may be explained by inadequate excitation-contraction coupling and disturbed oxygen utilisation. ${ }^{19}$ It has been recognized that myocardial stunning may also occur when myocardial oxygen demand is transiently elevated in the presence of partial coronary stenosis. ${ }^{20}$

The severity and duration of postischaemic dysfunction are unpredictable and may vary considerably for apparently similar ischaemic insults. In experimental models, duration of ischaemia, amount of collateral perfusion, and left ventricular end-diastolic pressure are major determinants of postischaemic contractile dysfunction and recovery. However, the magnitude of regional dyskinesia during ischaemia and the indices of global systolic haemodynamics do not correlate with the rate of recovery. ${ }^{21}$

Stimulation of adenosine receptors before ischaemia significantly improves the postischaemic recovery of the thickening fraction. ${ }^{22}$ Recovery from stunning is also greatly facilitated by the ATP dependent potassium channel opener nicorandil. ${ }^{23}$
In a number of animal models, the protective role of anaesthetic agents on the stunned myocardium has been studied. After short periods of acute ischaemia, recovery of function is more complete in animals anaesthetized with halothane or isoflurane than in awake animals or in animals anaesthetized with fentanyl. ${ }^{24-26}$ However, the clinical implications of these findings are by no means clear.

\section{Myocardial hibernation}

In the 1970 s it became apparent that left ventricular function could be persistently depressed due to chronic ischaemia and that contractile function could be restored promptly with relief of ischaemia. This condition was termed myocardial hibernation by Rahimtoola. ${ }^{27}$

It is now clear that reductions of perfusion pressure are not associated with impaired ventricular function as long as they take place within the autoregulatory range. Where coronary blood flow is reduced below the autoregulatory range, function is reduced: perfusion and contraction are matched and the myocardium may be regarded as hibernating. This matching of perfusion and contraction can be considered as downregulation of function: when perfusion returns to normal, function improves. ${ }^{28}$ The rate (rapid or progressive) at which coronary flow is reduced in experimental ischaemia is an important determinant of the extent of injury. ${ }^{29}$ This suggests that downregulation of myocardial metabolism with gradually decreasing flow protects the increasingly compromised area.

The mechanisms of myocardial hibernation have not been fully elucidated. Interstitial adenosine may play a role in the downregulation of myocardial energy demand as purine nucleoside release peaks at 10 minutes of ischaemia and gradually returns to preischaemia levels. ${ }^{30}$

In clinical practice, myocardial hibernation is a condition of chronic left ventricular dysfunction associated with severe coronary artery disease whereby significant recovery of function occurs after revascularisation. The presence of contractile reserve may be assessed by dobutamine echocardiography. If administration of dobutamine improves wall motion, function will improve after revascularisation. ${ }^{31}$

Left ventricular dysfunction has an adverse prognosis. Therefore, attempts to protect the hibernating or recurringly stunned myocardium may be beneficial. Pharmacological interventions with beta-adrenoceptor blockers, angiotensin converting enzyme inhibitors, or calcium channel blockers ${ }^{32}$ may protect or improve function of hibernating myocardium. 


\section{Myocardial preconditioning}

In the phenomenon termed "ischaemic preconditioning," a brief period of ischaemia preceding a longer one improves myocardial function after reperfusion and diminishes infarct size. This phenomenon is triggered by several agents released by ischaemic cells and can be reproduced by infusion of adenosine, angiotensin, phenylephrine, bradykinin, and endothelin. All of these mediators are coupled to protein kinase $C$. The intracellular pathway includes a phospholipase and diacylglycerol. The end-effector that mediates protection is still unknown. ${ }^{33}$

There is increasing evidence that ATP sensitive potassium channels $\left(\mathrm{K}_{\mathrm{ATP}}\right)$ play a role in the developments of preconditioning. As the adenosine Al receptor is reported to be linked with the $\mathrm{K}_{\mathrm{ATP}}$ channel, ${ }^{34}$ it is not surprising that activation of adenosine receptors prior to a prolonged ischaemic period appears to mimic preconditioning in animal models. Thus an adenosine infusion just before cardiopulmonary bypass may be expected to improve post bypass cardiac function. Indeed, in a small control study cardiac index has been found to be higher in patients who had received a $10 \mathrm{~min}$ infusion of adenosine just before cardiopulmonary bypass. ${ }^{35}$

If brief episodes of ischaemia protect the myocardium, repeated brief coronary occlusions during balloon angioplasty may precondition the myocardium and confer some protection, similar to the benefits of brief periods of occlusion described in experimental animal models. Such preconditioning has been reported in patients undergoing coronary angioplasty. ${ }^{36}$ The administration of glibenclamide, an inhibitor of the $\mathrm{K}_{\mathrm{ATP}}$ channel appears to abolish preconditioning during coronary angioplasty, ${ }^{37}$ suggesting that $\mathrm{K}_{\mathrm{ATP}}$ channels play an important role in human preconditioning. Also, there is some controversy concerning the induction of conditioning by coronary angioplasty as a recent study of ECG and wall motion changes during angioplasty did not demonstrate preconditioning. ${ }^{38}$

\section{Coronary steal and anaesthesia}

Drugs that dilate the coronary resistance vessels may cause redistribution of coronary blood flow away from the subendocardium and away from the most compromised areas of the myocardium, a situation described as coronary steal. It has been suggested that the development of a steal phenomenon is more likely to occur in the presence of steal-prone anatomy of the coronary arteries. This situation is present in approximately $25 \%$ of patients with coronary artery disease documented angiographically and consists of the occlusion of a ves- sel, the stenosis of another, and demonstrable collaterals between these vascular territories. ${ }^{39}$

Continuous ECG monitoring in patients undergoing coronary artery bypass surgery has revealed that patients with steal-prone anatomy have more frequent and longer ECG episodes of ischaemia preoperatively. ${ }^{40}$ However, the importance of a steal-prone anatomy as a factor of risk for myocardial ischaemia in surgical patients has been questioned. In several studies the incidence of adverse cardiac outcome was no different in patients with and in patients without stealprone anatomy. 41.42

Several inhalational anaesthetics cause coronary vasodilatation, notably isoflurane, desflurane and sevoflurane. In a multiplicity of experimental animal models a coronary steal has been demonstrated. ${ }^{43-45}$ In patients with documented coronary artery disease, isoflurane has been reported to cause coronary steal for the first time in 1983 by Reiz and colleagues. ${ }^{46}$ More recently a study has examined the risk of myocardial ischaemia associated with isoflurane or enflurane anaesthesia. Haemodynamics were controlled in both groups of patients. While there was no difference in incidence of ischaemia before anaesthesia, $50 \%$ of patients receiving isoflurane developed ischaemia $v s \mathbf{2 0 \%}$ of those receiving enflurane. ${ }^{47}$ There is also anecdotal evidence of the development of ischaemia with the administration of isoflurane and of its disappearance with its withdrawal. A case in point is the recent report of the development of myocardial ischaemia (ST segment depression and haemodynamic compromise) in a patient who received isoflurane and thoracic epidural analgesia. The changes disappeared when isoflurane was discontinued. ${ }^{48}$ However, some large studies comparing several inhalational anaesthetics and opioids have failed to demonstrate an increased frequency of adverse outcome associated with the administration of isoflurane. ${ }^{42,49}$

Desflurane, like isoflurane, is a coronary vasodilator. ${ }^{50}$ Therefore it could be anticipated to cause redistribution of coronary blood flow in animal models of stenoses with development of collateral vessels. Indeed, such redistribution has been reported by Hartman and colleagues. ${ }^{51}$ However, when haemodynamics were maintained at preanaesthesia levels, redistribution of coronary blood flow did not occur even in the presence of high concentrations of desflurane.

Sevoflurane also produces direct vasodilatation of the coronary arteries in vitro and reduces coronary vascular resistance in vivo. Therefore, it could be expected to cause coronary steal. However, in a model of progressive coronary artery stenosis and collateral development, sevoflurane did not cause redistribution 
of myocardial blood flow, ${ }^{52}$ suggesting that vasodilatation in vivo is of relatively small magnitude.

A recent, more complex study may explain why the results of experimental studies are not always consistent. In a canine model, in which collateral blood flow had been allowed to develop, Mignella and Buffington ${ }^{53}$ found that halothane, isoflurane and desflurane did not affect the coronary resistance of collateral segments. However, the downstream resistance of the artery supplying the collaterals was decreased more by desflurane $(-45 \%)$, than by isoflurane $(-35 \%)$, or halothane $(-15 \%)$. In addition, retrograde flow was unaffected by isoflurane and halothane but decreased by desflurane. In the face of such diverse effects it is not surprising that the changes brought about by anaesthetic agents depend upon the model used.

\section{Conclusions}

The effects of anaesthesia on the compromised heart are complex. They depend exquisitely upon the type of any ischaemic threat, the level of autonomic nervous system activity, and the quality of the endothelium. In the face of acute coronary occlusion, most anaesthetic agents minimize the extent of ischaemia and limit infarct size. In the face of critical or supracritical coronary stenosis, anaesthetic agents which decrease pressure cause selectively exaggerated depression of compromised myocardium. ${ }^{14}$ The possibility of exaggerated myocardial depression also exists when agents cause coronary vasodilatation. ${ }^{44}$ However, inhalational anaesthetics appear to protect the stunned myocardium. ${ }^{23-26}$ The overall effect of anaesthetic agents on the myocardium will be the result of the balance struck between several complex effects. It is probably because of the complexity of the regulation of the coronary circulation in patients with ischaemic heart disease and the varied effects of anaesthetic agents on the compromised heart that outcome appears to be little influenced by the choice of the anaesthetic agent. The quality of the control of the circulation (blood pressure, heart rate) throughout the perioperative period is likely to play a more important role that the choice of the anaesthetic agent.

\section{References}

1 Opie LH. Oxygen supply: coronary flow. In: The Heart, Physiology and Metabolism, 2nd ed. New York: Raven Pess. 1991: 277-300.

2 Mubagwa K, Mullane K, Flameng $W$. Role of adenosine in the heart and circulation. Cardiovasc Res 1996; 32: 797-813.

3 Losano G, Pagliaro P, Gattullo D, Marsh NA. Control of coronary blood flow by endothelial release of nitric oxide. Clin Exp Pharmacol Physiol 1994; 21 : 783-9.
4 van Hinsbergh VW. Regulatory functions of the coronary endothelium. Mol Cell Biochem 1992; 116: 163-9.

5 Bassenge E. Control of coronary blood flow by autacoids. Basic Res Cardiol 1995; 90: 125-41

6 Mehta $J L$. Endothelium, coronary vasodilation, and organic nitrates. Am Heart J 1995; 129: 382-91.

7 Rubanyi GM, Polokoff MA. Endothelins: molecular biology, biochemistry, pharmacology, physiology, and pathophysiology. Pharmacol Rev 1994; 46: 325-415.

8 Young MA, Vatner DE, Vatner SF. Alpha- and betaadrenergic control of large coronary arteries in conscious calves. Basic Res Cardiol 1990; 85(Suppl 1): 97-109.

9 DeFily DV, Patterson JL, Chilian WM. Endogenous adenosine modulates alpha 2-but not alpha 1-adrenergic constriction of coronary arterioles. Am J Physiol 1995; 268: H2487-94.

10 Reid JV, Ito BR, Huang AH, Buffington CW, Feigl EO. Parasympathetic control of transmural coronary blood flow in dogs. Am J Physiol 1985; 249: H337-43.

11 Kaski JC, Crea F, Meran D, et al. Local coronary supersensitivity to diverse vasoconstrictive stimuli in patients with variant angina. Circulation 1986; 74: 1255-65.

12 Baumgart D, Heusch G. Neuronal control of coronary blood flow. Basic Res Cardiol 1995; 90: 142-59.

13 Ito BR, Feigl EO. Carotid chemoreceptor reflex parasympathetic coronary vasodilation in the dog. Am J Physiol 1985; 249: H1167-75.

14 Lowenstein E, Foëx P, Francis CM, Davies WL, Yusuf $S$, Ryder WA. Regional ischemic ventricular dysfunction in myocardium supplied by a narrowed coronary artery with increasing halothane concentrations in the dog. Anesthesiology 1981; 55: 349-59.

15 Leone BJ, Norris RM, Safwat A, Foëx P, Ryder WA. Effects of progressive myocardial ischaemia on systolic function, diastolic function, and load dependent relaxation. Cardiovasc Res 1992; 26: 422-9.

16 Meyer TE, Fö̈x P, Ryder WA. Regional interaction and its effect on patterns of myocardial segmental shortening and lengthening during different models of asynchronous contraction in the dog. Cardiovasc Res 1992; 26: 476-86.

17 Marsch SCU, Wanigasekera VA, Ryder WA, Wong LSS, Fö̈x $P$. Graded myocardial ischemia is associated with a decrease in diastolic distensibility of remote nonischemic myocardium in anesthetized dog. J Am Coll Cardiol 1993; 22: 899-906.

18 Braunwald E, Kloner $R A$. The stunned myocardium: prolonged, postischemic ventricular dysfunction. Circulation 1982; 66: 1146-9.

19 Schipke JD, Korbmacher B, Dorszewski A, Selcan G, Sunderdick $U$, Arnold $G$. Haemodynamic and energetic 
properties of stunned myocardium in rabbit hearts. Heart 1996; 75: 55-61.

20 Thaulow E, Guth BD, Heusch G, et al. Characteristics of regional myocardial stunning after exercise in dogs with chronic coronary stenosis. Am J Physiol 1989; 257: H113-9.

21 Wouters $P F$, Van de Velde $M$, Van Aken H, Flameng $W$. Ischemic event characteristics determine the extent of myocardial stunning in conscious dogs. Basic Res Cardiol 1996; 91: 140-6.

22 Ogawa T, Miura $T$, Shimamoto K, Iimura $O$. Activation of adenosine receptors before ischemia enhances tolerance against myocardial stunning in the rabbit heart. J Am Coll Cardiol 1996; 27: 225-33.

23 Warltier DC, Auchampach JA, Gross GJ. Relationship of severity of myocardial stunning to ATP dependent potassium channel modulation. J Card Surg 1993; 8 (2 Suppl): 279-83.

24 Warltier DC, Al-Wathiki MH, Kampine JP, Schmeling $W T$. Recovery of contractile function of stunned myocardium in chronically instrumented dogs is enhanced by halothane or isoflurane. Anesthesiology 1988; 69: 552-65.

25 Kanaya N, Kobayashi I, Nakayama M, Fujita $S$, Namiki A. ATP sparing effect of isoflurane during ischaemia and reperfusion of the canine heart. $\mathrm{Br} \mathrm{J}$ Anaesth 1995; 74: 563-8.

26 White JL, Myers AK, Analouei A, Kim YD. Functional recovery of stunned myocardium is greater with halothane than fentanyl anaesthesia in dogs. $\mathrm{Br} \mathrm{J}$ Anaesth 1994; 73: 214-9.

27 Rabimtoola SH. A perspective on the three large multicenter randomized clinical trials of coronary bypass surgery for chonic stable angina. Circulation 1985; 72 (Suppl V): V123-35.

28 Schipke JD. Myocardial hibernation. Basic Res Cardiol 1995; 90: 26-8.

29 Ito BR. Gradual onset of myocardial ischemia results in reduced myocardial infarction. Association with reduced contractile function and metabolic downregulation. Circulation 1995; 91: 2058-70.

30 Gao ZP, Downey HF, Fan WL, Mallet RT. Does interstitial adenosine mediate acute hibernation of guinea pig myocardium? Cardiovasc Res 1995; 29: 796-804.

31 Afridi I, Kleiman NS, Raizner AE, Zoghbi WA. Dobutamine echocardiography in myocardial hibernation. Optimal dose and accuracy in predicting recovery of ventricular function after coronary angioplasty. Circulation 1995; 91: 663-70.

32 Sheiban I, Tonni S, Marini A, Trepi G. Clinical and therapeutic implications of chronic left ventricular dysfunction in coronary artery disease. Am J Cardiol $1995 ; 75: 23 \mathrm{E}-30$.
33 Cohen MV, Downey JM. Myocardial preconditioning promises to be a novel approach to the treatment of ischemic heart disease. Annu Rev Med 1996; 47: 21-9.

34 Cason BA, Gordon HJ, Avery EG, Hickey RF. The role of ATP sensitive potassium channels in myocardial protection. J Card Surg 1995; 10: 441-4.

35 Lee HT, LaFaro RJ, Reed GE. Pretreatment of human myocardium with adenosine during open heart surgery. J Card Surg 1995; 10: 665-76.

36 Deutsch E, Berger M, Kussmaul WG, Hirshfeld JW, Herrmann HC, Laskey WK. Adaptation to ischemia during percutaneous transluminal coronary angioplasty. Clinical, hemodynamic, and metabolic features. Circulation 1990; 82: 2044-55.

37 Tomai F, Crea F, Gaspardone A, et al. Ischemic preconditioning during coronary angioplasty is prevented by glibenclamide, a selective ATP-sensitive $\mathrm{K}+$ channel blocker. Circulation 1994; 90: 700-5.

38 Dupouy P, Geschwind H, Pelle G, et al. Repeated coronary artery occlusions during routine balloon angioplasty do not induce myocardial preconditioning in humans. J Am Coll Cardiol 1996; 27: 1374-80.

39 Buffington $C W$, Davis $K B$, Gillispie $S$, Pettinger $M$. The prevalence of steal-prone coronary anatomy in patients with coronary artery disease: an analysis of the Coronary Artery Surgery Study Registry. Anesthesiology 1988; 69: 721-7.

40 Hogue CW, Herbst TJ, Pond C, Apostolidou I, Lappas $D G$. Perioperative myocardial ischemia. Its relation to anatomic pattern of coronary artery stenosis. Anesthesiology 1993; 79: 514-24.

41 Leung JM, Hollenberg $M, O^{\prime}$ Kelly $B F, K a o$, Mangano $D T$. Effects of steal-prone anatomy on intraoperative myocardial ischemia. The SPI Research Group. J Am Coll Cardiol 1992; 20: 1205-12.

42 Slogoff $S$, Keats $A S$, Dear WE, et al. Steal-prone coronary anatomy and myocardial ischemia associated with four primary anesthetic agents in humans. Anesth Analg 1991; 72: 22-7.

43 Buffington $C W$, Romson $\Pi$, Levine A, Duttlinger $N C$, Huang $A H$. Isoflurane induces coronary steal in a canine model of chronic coronary occlusion. Anesthesiology 1987; 66: 280-92.

44 Priebe $H-J$, Foëx $P$. Isoflurane causes regional myocardial dysfunction in dogs with critical coronary artery stenoses. Anesthesiology 1987; 66: 293-300.

45 Nathan HJ, Smallman B. Isoflurane, compared to halothane or enflurane, causes increased lactate production but no transmural coronary steal during myocardial ischemia in swine. Anesth Analg 1993; 77: 211-20.

46 Reiz $S$, Balfors $E$, Sorensen $M B$, Ariola $S$, Friedman $A$, Truedsson $H$. Isoflurane - a powerful coronary 
vasodilator in patients with coronary artery disease. Anesthesiology 1983; 59: 91-7.

47 Diana P, Tullock WC, Gorcsan J, Ferson PF, Arvan S. Myocardial ischemia: a comparison between isoflurane and enflurane in coronary artery bypass patients. Anesth Analg 1993; 77: 221-6.

48 Sigurdsson GH, Brouwer RP, Thomson D. Repeated episodes of myocardial ischaemia during combined thoracic epidural-isoflurane anaesthesia. Acta Anaesthesiol Scand 1994; 38: 521-4.

49 Forrest JB, Cabalan $M K$, Rebder $K$, et al. Multicenter study of general anesthesia. II. Results. Anesthesiology 1990; 72: 262-8.

50 Warltier DC, Pagel PS. Cardiovascular and respiratory actions of desflurane: is desflurane different from isoflurane? Anesth Analg 1992; 75(4 Suppl): S17-29; discussion S29-31.

51 Hartman JC, Pagel PS, Kampine JP, Schmeling WT, Warltier DC. Influence of desflurane on regional distribution of coronary blood flow in a chronically instrumented canine model of multivessel coronary artery obstruction. Anesth Analg 1991; 72: 289-99.

52 Kersten JR, Brayer AP, Pagel PS, Tessmer JP, Warltier $D C$. Perfusion of ischemic myocardium during anesthesia with sevoflurane. Anesthesiology 1994; 81: 995-1004.

53 Mignella $R$, Buffington $C W$. Inhaled anesthetics alter the determinants of coronary collateral blood flow in the dog. Anesthesiology 1995; 83: 799-808. 
Pierre Foëx MA DPHIL FRCA FANZCA, S.J. Howell MSC MRCP FRCA

\section{Le myocarde}

A U cours des dernières années, nous avons assisté à la naissance de concepts nouveaux et importants en rapport avec le coeur et la circulation coronaire. Ces concepts influencent la pratique de l'anesthésie et des soins intensifs. Ils seront discutés sous les rubriques suivantes : le contrôle humoral, hormonal et local de la circulation coronaire, les effets de l'ischémie sur la fonction cardiaque, incluant le «stunning» du myocarde, l'hibernation et la préconditionnement, et, finalement, le vol coronaire.

\section{Le contrôle de la circulation coronaire}

Le débit sanguin coronaire est normalement contrôlé par les altérations de la résistance des artérioles intramyocardiques. L'augmentation de la dégradation de l'ATP provoque une ćlévation de la concentration d'adénosine, un puissant relaxant endogène des muscles vasculaires lisses. Ce mécanisme local permet au flux sanguin coronaire de s'adapter aux besoins en oxygène. ${ }^{1,2}$ La circulation coronaire est aussi contrôlée par d'autres médiateurs dont le monoxyde d'azote, la prostacycline, le thromboxane et les endothélines. ${ }^{3-5}$ Ces médiateurs sont synthétisés et libérés par l'endothélium dont la fonction est souvent perturbée par l'athéromatose. Un déséquilibre entre les médiateurs entraîne le dérèglement de la vasoconstriction, l'agrégation des plaquettes et la formation du thrombus. ${ }^{6}$ Comme elles connnues sont parmi les plus puissants vasoconstricteurs connus, les endothélines peuvent influencer la genèse de ces événements.?

\section{Le contróle neurogène}

L'activation du système nerveux sympathique provoque des changements marqués du flux sanguin coronaire. Ces changements sont rendues possibles, en partic, par les altérations de la demande métabolique. Cependant, les mécanismes alpha- et bêta-adrénergiques contrôlent artères coronaires de petit et de gros calibre. Les adrénorécepteurs alpha $a_{1}$ et alpha ${ }_{2}$ provoquent de la vasoconstriction, alors que les adrénorécepteurs bêta ${ }_{1}$ et bêta ${ }_{2}$ entrent en compétition avec la vasodilatation d'origine métabolique. Cette compétition est atténuée par la production endogène d'adénosine. Enfin, l'adénosine module la vasoconstriction due à la stimulation des adrénorécepteurs alpha ${ }_{2}$ mais non à celle des alpha ${ }_{1}$.

Comme la bradycardie et l'hypotension diminuent la demande en oxygène, l'activation du système parasympathique produit habituellement une réduction du flux sanguin coronaire. Toutefois, si, par entraînement systolique, on prévient la bradycardie causée par la stimulation vagale, le flux sanguin coronaire augmente de façon uniforme à travers la paroi ventriculaire gauche en réponse à la stimulation vagale. Par contre, l'acétylcholine dilate les vaisseaux sous-endocardiques de façon préférentielle. ${ }^{10}$

Alors qu'on a longtemps sous-estimé le rôle du système nerveux autonome, plusieurs études reconnaissent maintenant l'existence d'une hypersensibilité locale aux vasoconstricteurs dans l'angine de Prinzmetal. ${ }^{11} \mathrm{La}$ constriction alpha-adrénergique des vaisseaux coronaires de résistance peut entraîner une ischémie myocardique poststénotique dans l'angine d'effort, ce qui a été démontré à la fois en laboratoire et en clinique. D'autre part, les effets nocifs de la stimulation bêtaadrénergique résultent de la tachycardie et de la redistribution du débit sanguin coronaire causé par celle-ci ; la vasodilatation perd alors son importance fonctionnelle en présence de tachycardie. ${ }^{12}$

Les barorécepteurs carotidiens influencent le contrôle de la circulation coronaire: l'hypertension provoque au niveau du sinus carotidien une vasodilatation coronaire neurogène réflexe, progressive et indépendante des facteurs métaboliques myocardiques. Cette vasodilatation semble être principalement causée par l'activation des fibres parasympathiques coronaires vasodilatatrices. ${ }^{13}$

\section{L'ischémie myocardique}

L'ischémie myocardique régionale progressive provoque une réduction graduelle du raccourcissement systolique (épaississement) des fibres cardiaques associées aux anomalies de la motilité pariétale comme l'allongement protosystolique (amincissement) et le raccourcissement postsystolique (épaississement). ${ }^{14,15}$ En clinique, ces anomalies de la motilité pariétale sont décrites comme de l'hypokinésie (réduction de la motilité de la paroi), de l'akinésie (absence de mouvement de la paroi) et de la dyskinésie (mouvement paradoxal de la paroi). À cause des interactions régionales, on observe souvent pendant l'ischémie régionale une augmentation de la motilité du myocarde distant et normalement perfusé. ${ }^{16}$

On reconnait maintenant que dans la cardiopathie ischémique et hypertensive, la fonction diastolique peut être altérée avant que le fonction systolique ne le soit. L'ischémie myocardique aiguë provoque des altérations profondes de la fonction diastolique. À cause de la désynchronisation de la relaxation isovolumique (rac- 
courcissement ou épaississement postsystolique), la constante de temps de la relaxation isovolumique $(\tau)$ est prolongée. Au niveau des segments ischémiques, la vitesse maximale de l'allongement (ou de l'amincissement) est réduite, une conséquence directe de la diminution de l'étendue du raccourcissement (épaississement) systolique. En outre, la rigidité du myocarde augmente. Cette augmentation est directement proportionnelle à la gravité de l'ischémie et atteint son maximum au moment de l'occlusion coronaire. Bien que les mécanismes en soient encore inconnus, l'ischémie régionale myocardique s'accompagne aussi d'une augmentation de la rigidité du myocarde distant mais bien perfusé. ${ }^{17}$ Cet effet à distance de l'ischémie peut contribuer à augmenter la pression télédiastolique ventriculaire gauche observée pendant les épisodes d'ischémie régionale.

Pendant plusieurs années, on a cru que les épisodes prolongés d'ischémie profonde causaient des lésions myocardiques irréversibles, c.-à-d. l'infarctus du myocarde, alors que les épisodes brefs d'ischémie étaient suivis d'une récupération rapide et totale. Cette conception a été mise en doute et les notions de «stunning" et d'hibernation myocardiques ont fait leur apparition. On reconnaît maintenant que l'ischémie myocardique peut évoluer vers l'insuffisance ventriculaire par dommage irréversible (mort cellulaire), stunning myocardique ou hibernation myocardique.

\section{Le «stunning» myocardique}

En 1982, Braunwald et Kloner ont créé le terme «stunning» pour décrire le dysfonctionnement prolongé de la contractilité qui persiste après une ischémie aiguë grave suivie de reperfusion. ${ }^{18}$ Cette dysfonction comprend la diminution de la fonction systolique (stunning systolique) et l'augmentation de la rigidité myocardique (stunning diastolique). Le stunning myocardique peut s'expliquer par la défaillance du couplage excitationcontraction et par la perturbation de l'utilisation de l'oxygène. ${ }^{19}$ Le stunning myocardique peut aussi survenir quand la demande en oxygène s'élève temporairement en présence d'une sténose coronaire partielle. ${ }^{20}$

La gravité et la durée du dérèglement postischémique est imprévisible et peut varier considérablement entre des attaques ischémiques pourtant identiques. Sur des modèles expérimentaux, la durée de l'ischémie, l'abondance de la perfusion collatérale, et la pression télédiastolique ventriculaire gauche sont tous des facteurs déterminant le dérèglement postischémique de la contractilité et sa récupération. Cependant, l'ordre de grandeur de la dyskinésie régionale pendant l'ischémie et les indices hémodynamiques globaux manquent de corrélation avec le taux de récupération. ${ }^{21}$
La stimulation préischémique des récepteurs de l'adénosine améliore de façon appréciable la récupération postischémique de la fraction d'épaississement. ${ }^{22}$ La récupération du stunning est aussi grandement facilitée par l'ouverture par le nicorandil des canaux potassiques ATP dépendants. ${ }^{23}$

Le rôle protecteur des agents anesthésiques sur le myocarde atteint de stunning a été étudié sur des préparations animales. Après de courts épisodes d'ischémie aiguë, la récupération fonctionnelle est plus complète chez les animaux anesthésiés à l'halothane et à l'isoflurane que ceux qu'on a maintenu éveillés ou anesthésiés au fentanyl. ${ }^{24-26}$

\section{L'hibernation myocardique}

Dans les années 1970, il est devenu apparent que la fonction ventriculaire gauche pouvait être déprimée de façon durable par l'ischémie chronique et que la contractilité pouvait être rapidement restaurée en éliminant l'ischémie. Cette condition a été appelée hibernation myocardique par Rahimtoola. ${ }^{27}$

On sait maintenant que les baisses de la pression de perfusion ne sont pas associées à un dérèglement de la fonction ventriculaire pour autant qu'elles demeurent à l'intérieur des limites de l'autorégulation. Lorsque le flux sanguin coronaire diminue au dessous du seuil de l'autorégulation, la fonction diminue ; pour autant que la perfusion et la contractilité demeurent appariées, on considère que le myocarde hiverne. L'appariement de la perfusion avec la contraction peut être considéré comme de la régulation fonctionnelle à la baisse ; quand la perfusion revient à la normale, la fonction s'améliore. ${ }^{28}$ Pendant l'ischémie expérimentale, le taux (rapide ou lent) de réduction du flux coronaire détermine de façon substantielle de la lésion. ${ }^{29}$ Ceci suggère que la régulation à la baisse du métabolisme myocardique associée à un flux sanguin rapidement décroissant protège une région progressivement exposée.

Le mécanisme de l'hibernation myocardique n'est pas complètement élucidé. Comme la libération de la nucléoside purique atteint son maximum après 10 minutes d'ischémie et retourne graduellement au niveau préischémique, on peut conclure que l'adénosine interstitielle pourrait influencer la régulation à la baisse de la demande énergétique myocardique. ${ }^{30}$

L'hibernation myocardique équivaut cliniquement à une condition de dysfonctionnement ventriculaire gauche chronique associée à l'insuffisance coronaire grave au cours de laquelle une récupération importante de la fonction survient après la revascularisation. L'existence d'une réserve de contractilité peut être confirmée par l'échocardiographie à la dobutamine. Si 
l'administration de la dobutamine restaure la motilité pariétale, les chances sont que la fonction s'améliorera après la revascularisation. ${ }^{31}$

Le pronostic du dysfonctionnement ventriculaire gauche est mauvais. Par conséquent, toute tentative de protection du myocarde en hibernation ou sous l'effet d'un stunning répété peut être profitable. L'administration de bloquants bêta-adrénergiques, d'inhibiteurs de l'enzyme de conversion, ou d'inhibiteurs calciques ${ }^{32}$ peut protéger ou même améliorer le fonctionnement du myocarde en hibernation.

\section{Le préconditionnement myocardique}

Au cours du phénomène appelé «préconditionnement ischémique», une courte période d'ischémie qui en précède une plus longue période améliore la fonction myocardique après la reperfusion et diminue la dimension de l'infarctus. Ce phénomène est déclenché par plusieurs agents libérés par les cellules ischémiques et peut être reproduit avec une perfusion d'adénosine, d'angiotensine, de phényléphrine, de bradykinine et d'endothéline. Tous ces médiateurs sont couplés à la protéine kinase $\mathrm{C}$. La chaîne de conduction intracellulaire contient une phospholipase et du diacylglycérol. Le médiateur terminal qui effectue la protection demeure inconnu. ${ }^{33}$

L'influence des canaux potassiques sensibles à l'ATP ( $\left.\mathrm{K}_{\text {ATP }}\right)$ dans la genèse du préconditionnement paraît de plus en plus plausible. Comme le récepteur adénosinique Al semble lié aux canaux $\mathrm{K}_{\mathrm{ATP}}{ }^{34}$ on peut comprendre que l'activation des récepteurs adénosiniques sur un modèle animal avant un épisode prolongé d'ischémie ressemble en tout point au préconditionnement myocardique. Une perfusion d'adénosine immédiatement avant la circulation extracorporelle (CEC) devrait donc améliorer la fonction cardiaque après la CEC. Effectivement, on a trouvé au cours d'une étude contrôlée d'un petit nombre de patients, que l'index cardiaque était plus élevé après une perfusion d'une durée de 10 minutes d'adénosine administrée immédiatement avant la CEC. ${ }^{35}$

$\mathrm{Si}$ les épisodes d'ischémie de courte durée protègent le myocarde, les occlusions brèves et répétées de l'angioplastie par ballonnet pourraient préconditionner le myocarde et offrir un certain degré de protection, identique à celui procuré par des occlusions et déjà rapporté sur une préparation animale expérimentale. Ce type de préconditionnement a aussi été rapporté chez des patients soumis à une angioplastie coronaire. ${ }^{36}$ L'administration de glibenclamide, un inhibiteur des canaux $\mathrm{K}_{\mathrm{ATP}}$ semble abolir le préconditionnement pendant l'angioplastie coronaire, ${ }^{37}$ suggérant ainsi chez l'humain le rôle important des canaux $\mathrm{K}_{\mathrm{ATP}}$ dans le préconditionnment. Toutefois, l'induction d'un conditionnement par l'angioplastie coronaire demeure controversé étant donné que, pendant l'angioplastie, les changements de la motilité pariétale ne démontrent pas son développement. ${ }^{38}$

\section{Le vol coronaire et l'anesthésie}

Les vasodilatateurs coronaires de résistance peuvent provoquer la redistribution du flux sanguin et en priver la région sous-endocardique et les régions les plus malades du myocarde, un phénomène appelé vol myocardique. L'apparition du phénomène de vol serait selon certains auteurs favorisée par la configuration anatomique des artères coronaires. L'angiographie a montré que cette configuration se présentait chez environ $25 \%$ des coronariens. Elle consiste en l'occlusion d'un vaisseau, la sténose d'un autre et de collatérales visibles entre les deux territoires vasculaires. ${ }^{39}$

Le monitorage ECG continu réalisé en vue d'une chirurgie de revascularisation myocardique a révélé que les patients anatomiquement prédisposés au vol coronaire présentaient à l'ECG des épisodes préopératoire ischémiques plus fréquents et de plus longue durée..$^{40}$ L'importance d'une anatomie spécifique au vol coronaire comme facteur de risque d'ischémie myocardique a toutefois été mise en doute. Plusieurs comptes rendus ont révélé que l'incidence des complications ne différait pas chez les patients qu'ils soient anatomiquement susceptibles ou non. ${ }^{41,42}$

Plusieurs anesthésiques volatils dilatent les coronaires, spécialement l'isoflurane, le desflurane et le sévoflurane. Un grande nombre d'études de laboratoire ont démontré le vol coronaire sur des animaux. ${ }^{43-54}$ Chez le coronarien reconnu, Reiz et al. en $1983^{46}$ ont montré pour la première fois que l'isoflurane entraînait un vol coronaire. Une étude plus récente a comparé le risque d'ischémie myocardique associé à l'isoflurane et à l'enflurane. Les paramètres hémodynamiques étaient contrôlés dans les deux groupes de patients. Avant l'anesthésie, l'incidence de l'ischémie étant la même, $50 \%$ des patients ont développé de l'ischémie sous isoflurane comparativement à $20 \%$ sous enflurane. ${ }^{47}$ Des comptes rendus anecdotique ont fait état d'ischémie apparue pendant l'administration de l'isoflurane qui disparaissait lorsqu'on la cessait. Plus particulièrement, un article récent mentionnait l'apparition d'ischémie myocardique (dépression du segment ST avec altérations hémodynamiques) chez un patient sous anesthésie à l'isoflurane associée à une anesthésie péridurale thoracique. Ces altérations sont disparues avec l'arrêt de $1^{1}$ 'isoflurane. ${ }^{48}$ Cependant, des études comparant plusieurs anesthésiques par inhalation aux morphiniques n'ont pas démontré que la fréquence de résultats défavorables augmentait avec l'utilisation de l'isoflurane. ${ }^{42,49}$ 
Le desflurane, comme l'isoflurane est un vasodilatateur coronaire. ${ }^{50}$ On devrait donc s'attendre à ce qu'il provoque la redistribution du flux sanguin avec organisation d'une circulation collatérale sur des modèles de sténoses animales. Hartman et al. ont effectivement rapporté ce phénomène. ${ }^{51}$ Cependant, lorsqu'ils maintenaient les paramètres hémodynamiques au niveau préanesthésique, le flux sanguin n'était pas redistribué même en présence de concentrations élevées de desflurane.

Le sévoflurane provoque aussi une vasodilatation directe des artères coronaires in vitro et diminue la résistance coronaire vasculaire in pivo. Le sévoflurane devrait donc favoriser le vol coronaire. Cependant, sur un modèle de sténose progressive coronaire avec développement d'une circulation, le sévoflurane n'a pas provoqué de redistribution du flux sanguin coronaire, ${ }^{52}$ ce qui porte à croire que, in vivo, la vasodilatation est relativement peu importante.

Une étude récente plus complexe peut expliquer pourquoi les résultats des études expérimentales sont inconsistents. Mignella et Buffington ${ }^{53}$ ont trouvé que ni l'halothane ni l'isoflurane ni le desflurane n'affectaient la résistance de segments coronaires collatéraux sur un modèle canin qui comportait le developpement d'une circulation collatérale. Cependant, en aval, la résistance de l'artère nourricière des collatérales diminuait plus nettement sous desflurane $(-45 \%)$ que sous isoflurane $(-35 \%)$, et halothane $(-15 \%)$. En outre, le courant rétrograde n'était pas affectés par l'isoflurane et l'halothane mais diminuait avec le desflurane. En face d'une telle diversité de résultats, on ne peut que conclure que les changements provoqués par les anesthésiques dépendent du modèle utilisé.

\section{Conclusions}

Les effets de l'anesthésie sur le coeur malade sont complexes. Ils dépendent particulièrement du type de menace ischémique, du niveau d'activité du système nerveux autonome et de la qualité de l'endothélium. En face d'une occlusion coronaire aiguë, la plupart des agents anesthésiques réduisent au minimum l'étendue de l'ischémie et limite la dimension de l'infarctus. Face à une sténose coronaire critique ou supracritique, les anesthésiques qui abaissent la pression produisent une dépression exagérée sélective du myocarde compromis. ${ }^{14}$ Il est possible que la dépression myocardique soit amplifiée par les anesthésiques qui entrainaient une vasodilatation coronaire. ${ }^{44}$ Cependant, lors du stunning, les anesthésiques volatils semblent protéger le myocarde. ${ }^{23-26}$ L'effet global des anesthésiques sur le myocarde est le résultat de l'équilibre établi entre plusieurs effets complexes. La complexité de la régula- tion de la circulation coronaire dans la coronaropathie et la grandes variété des effets anesthésiques sur le coeur malade peut expliquer pourquoi le choix de l'agent anesthésique a peu d'influence sur la fréquence des complications cardiovasculaires de l'anesthésie et de la chirurgie. La qualité du contrôle de la circulation (pression artérielle, fréquence cardiaque) pendant la période périopératoire est susceptible de jouer un rôle plus important que le choix de l'anesthésique.

\section{Références}

(Voir page R70) 